Neven Kočila, mag. iuris. ${ }^{1}$

\title{
OSNIVANJE I PRAVNA NARAV JAVNOBILJEŽNIČKOG POLOGA
}

\author{
UDK: $347.961(4)$ \\ DOI: $10.31141 /$ zrpfs.2019.56.133.685 \\ Pregledni znanstveni rad \\ Primljeno: 1. 04. 2019.
}

\begin{abstract}
U okviru javnobilježničke službe javni bilježnik obavlja poslove depozitara. Vidljiva je tendencija sve češćeg korištenja instituta javnobilježničkog pologa u slučajevima kada je osnivanje istog potrebno da bi se osiguralo ispunjenje uvjeta koji proizlaze iz osnovnog pravnog posla sklopljenog između ugovornih strana. Cilj je ovoga rada prikazati pravnu narav i načine osnivanja javnobilježničkog pologa. U središnjem dijelu rada daje se odgovor na pitanje predstavlja li osnivanje javnobilježničkog pologa poseban ugovorni odnos u kojem sudjeluje javni bilježnik kao ugovorna strana ili je riječ o jednostranoj službenoj radnji kojom javni bilježnik kao osoba javnog povjerenja postupa u okviru izvršavanja svoje opće službene dužnosti propisane Zakonom o javnom bilježništvu. Koriste se metoda analize, jezična i ciljna metoda pravnih propisa te metoda kompilacije korištenjem dostupne pravne literature. O pravnoj naravi ovog instituta ovisi primjena pravnih pravila u slučaju nastanka spora. U radu se korištenjem komparativne metode prikazuju uređenja iz Slovenije, Srbije, BiH, Njemačke, Rusije i Estonije.
\end{abstract}

Ključne riječi: javni bilježnik, javnobilježnički polog, ugovor o ostavi, ugovor o nalogu, opća službena dužnost, sudski polog

\section{UVOD}

Javnobilježnički polog sve se češće koristi kao način osiguranja plaćanja između sudionika trgovačkih odnosa u domaćem i u međunarodnom poslovanju. Pretežito se i dalje primarno koristi u poslovanju nekretninama, no prepoznaje se i njegova funkcija prilikom provođenja statusnih promjena u trgovačkim društvima, posebice kao instrumenta osiguranja plaćanja kupoprodajne cijene za poslovne udjele $\mathrm{u}$ društvu s ograničenom odgovornošću. Nema prepreke za korištenje ovog instituta ni npr. kod deponiranja autorskih djela, žigova i sl. Osnivanje javnobilježničkog pologa kao instrumenta osiguranja plaćanja korisno je i preporučljivo kod svih pravnih odnosa u kojima je strankama potrebno neutraliziranje rizika vezanog uz ispunjenje uvjeta iz osnovnog pravnog posla.

Cilj je ovoga rada analizirati pravnu narav i načine osnivanja javnobilježničkog pologa u Republici Hrvatskoj. U radu se polazi od pretpostavke da javni bilježnik u

1 Javnobilježnički savjetnik u uredu javnog bilježnika Marijana Jurića u Zagrebu 
osnivanju javnobilježničkog pologa kao neovisni i nepristrani povjerenik stranaka predstavlja vrstu escrow agenta sa svojim zakonski reguliranim pravima i obvezama. Ukazuje se stoga u tekstu na specifičnosti pravnog statusa javnog bilježnika kao escrow agenta u svojem postupanju, u odnosu na primjerice banku ili trgovačko društvo koji su kao escrow agenti u praksi učestaliji.

Primjenjivat će se metoda analize, jezična i ciljna (teleološka) metoda pravnih propisa te metoda kompilacije korištenjem postojeće pravne literature. U odgovarajućim dijelovima rada koristi se komparativna metoda i to jezičnim tumačenjem pravnih propisa u zemljama okruženja i zemljama za koje autor smatra da bi svojim pravnim uređenjem i dužom pravnom tradicijom mogle dati određene odgovore na pitanja koja se pojavljuju u radu. Komparativnim uspoređivanjem pravnih uređenja i iskustava u ovoj materiji nudi se mogućnost de lefe ferenda za uređenje našeg zakonodavnog okvira, kako bi ovaj instrument osiguranja plaćanja pružio sudionicima pravnih poslova što višu razinu pravne sigurnosti.

Hipoteza je ovoga rada da javnobilježnički polog prema trenutnom uređenju u Republici Hrvatskoj predstavlja mješoviti institut koji u sebi sadrži s jedne strane javnopravni element javnobilježničke službe izražen kroz obvezu poduzimanja službene radnje javnog bilježnika, a s druge strane poseban privatnopravni odnos između stranaka i javnog bilježnika. Taj privatnopravni odnos po svojoj naravi sadrži bitne značajke ugovora o ostavi i ugovora o nalogu, s učincima isključivo sudskog pologa. U odnosu na banke koje svojim ugledom jamče za nepristrano i uredno izvršenje naloga stranaka kao escrow agenti, javni je bilježnik prilikom postupanja dodatno podvrgnut i zakonskim propisima u skladu sa svojim položajem.

\section{O JAVNOBILJEŽNIČKOM POLOGU OPĆENITO}

Javni bilježnik u svome djelokrugu, kao samostalni i neovisni nositelj javnobilježničke službe sa svojstvom javnog povjerenja, između ostaloga, prima na čuvanje predmete (depozite) stranaka. Riječ je o depozitnoj funkciji javnog bilježnika. ${ }^{2}$ Prisutnost javnog bilježnika općenito sudionicima jamči kvalitetu, preciznost, pravnu zaštitu i zakonitost u postupanju. ${ }^{3}$

Navedena ovlast i funkcija proizlazi iz čl. 2. Zakona o javnom bilježništvu ${ }^{4} u$ kojem je propisano da se javnobilježnička služba sastoji, uz ostalo, od primanja na čuvanje isprava, novca i predmeta od vrijednosti radi njihove predaje drugim osobama ili nadležnim tijelima.

2 Dika, Mihajlo: "Javno bilježništvo i zaštita vjerovnika”, Pravo u gospodarstvu, vol. 34, br. 7-8, 1995., str. 547.

3 Vidi više u: Dika, Mihaljo: “Javnobilježnička služba u Republici Hrvatskoj”, Pravo i porezi, vol. 10., br. 12, 2001., Zagreb, str. 3-7.

4 Zakon o javnom bilježništvu (Narodne novine br. 78/93, 29/94, 162/98, 16/07, 75/09, 120/16), dalje: ZJB. 
Javnobilježnički polog (eng. notarial deposit, njem. notarielle Hinterlegung (češće u praksi pojam Treuhand, op. a.), franc. notarial dépôt) može se definirati kao novac, druge vrijednosnice, isprave i pokretnine koje se povjeravaju javnom bilježniku, u pravilu radi ispunjenja obveza, čuvanja ili predaje trećemu kada se za to ostvare pretpostavke. ${ }^{5}$

ZJB u svome tekstu ne daje izričitu definiciju i regulira javnobilježnički polog ovisno o predmetu preuzimanja na čuvanje. Navode se u tekstu ZJB-a kao mogući predmeti polaganja isprave, novac, vrijednosni papiri i dragocjenosti. Za potrebe ovoga rada, pojam ,deponirani predmet" obuhvaćat će u svom značenju sve vrijednosti koje ZJB predviđa kao prikladne za polaganje.

Korištenje javnobilježničkog pologa preporučljivo je kod onih transakcija u kojima se sama transakcija ne može dovršiti jer jedna od strana mora još ispuniti određene uvjete, ispunjenje kojih će se dokazati predajom dogovorenih dokumenata. ${ }^{6}$ Po svojoj naravi javnobilježnički polog najsličniji je escrow računu kao instrumentu osiguranja plaćanja koji nije posebno reguliran u našem pravu pozitivnim propisima, ali je obrađen u domaćoj pravnoj literaturi. ${ }^{7} \mathrm{~S}$ obzirom na to da kod javnobilježničkog pologa ulogu escrow agenta preuzima javni bilježnik kao nositelj javne službe i neovisni i nepristrani povjerenik stranaka, u radu se ukazuje na specifičnosti ovog escrow agenta u dijelu koji se odnosi na način osnivanja, pravnu narav i na pravne učinke javnobilježničkog pologa. Cilj je posljedično u radu dati odgovor na pitanje predstavlja li javnobilježnički polog zainteresiranim strankama učinkoviti instrument osiguranja plaćanja, odnosno primjenu kojih pravila sudionici mogu očekivati u slučaju nastanka eventualnog spora. Smatra li se osnivanje javnobilježničkog pologa pravnim poslom uz koji se vežu posebna javnopravna ovlaštenja, kao npr. u Njemačkoj, ${ }^{8}$ ili je riječ o profesionalnoj usluzi u kojoj javni bilježnik ulazi u posebni ugovorni odnos sa strankom?

Javni bilježnik kao neovisni i nepristrani sudionik u deponiranju ima ulogu povjerenika sukladno čl. 33. st. 2. ZJB-a. ${ }^{9}$ Pojam povjerenika (eng. Fiduciary povjerenik, opunomoćenik) kao escrow agenta prema pravnoj literaturi, označavao bi posebnu fiducijarnu dužnost (eng. fiduciary duty) javnog bilježnika da prema svim ugovornim stranama postupa s jednakom pažnjom, savjesnošću i brigom. ${ }^{10}$

5 Gl. urednik Vladimir Pezo: Pravni leksikon, Leksikografski zavod Miroslav Krleža, Zagreb, 2007., str. 1111.

6 Tako i za escrow account u Vukmir, Branko: Pravo međunarodnih plaćanja, Zagreb, 2007., str. 497, koja pravila bi se, prema mišljenju autora, na odgovarajući način trebala primjenjivati i na javnobilježnički polog kao vrstu escrowa.

7 Vidi više u: Vukmir, Branko: Pravo međunarodnih plaćanja, RRiF plus d.o.o., Zagreb, 2007., str. 493-508. Navode se i druga tijela kao escrow agenti, pri čemu bi to mogao biti i javni bilježnik ili trgovačka drušva kao što je uobičajeno npr. u SAD-u.

8 Knežić-Popović, Dragana: "Pravna priroda javnog beležništva", Pravni zapisi, Godina I, br. 2 (2010.), str. 358.

9 Više o pojmu nepristranosti i neovisnosti u javnom bilježništvu vidi: Prančić, Vicko: "O dužnosti poduzimanja i uskrati službene radnje javnog bilježnika”, Zbornik Pravnog fakulteta u Zagrebu, Vol. 58, br. 4/2008, str. 998-1000.

10 Op. cit. u bilj. 5, str. 501. za escrow račun. 
U hrvatskom se pravu ovaj pojam pretežito koristi kod obveze članova uprave na lojalno postupanje prema društvu ${ }^{11}$ i nije razvijen u okviru javnobilježničkog prava. Pojam se u okviru escrowa detaljnije analizirao kroz povijest u anglosaksonskom pravu gdje je razvijena vrlo bogata sudska praksa korištenjem instituta escrowa u osigurnju plaćanja, posebno na razini saveznih država. U američkom pravu se tako, između ostaloga, navodi da uloga povjerenika označava najviši stupanj pažnje u pravu pravičnosti (eng. equity of law). ${ }^{12}$ Najvažnija je dužnost depozitara ispuniti obveze i uvjete iz sporazuma o depozitu, ${ }^{13}$ postupajući pritom u dobroj vjeri (eng. good faith).$^{14}$ Postupanje depozitara ograničeno je jedino uputama stranaka određenima u sporazumu ${ }^{15}$ i nema nikakvu dužnost kontrolirati međusobne odnose stranaka. ${ }^{16} \mathrm{U}$ Hrvatskoj se značenje tog pojma u kontekstu javnobilježničkog depozita tek treba razviti u sudskoj praksi.

Javnobilježnički polog u hrvatskom pravu osniva se u pravilu davanjem naloga javnom bilježniku kao rezultat klauzule sadržane u temeljnom pravnom poslu sklopljenom između ugovornih strana, npr. u ugovoru o kupoprodaji nekretnina, ugovoru o kupoprodaji i prijenosu poslovnih udjela, ugovoru o prijenosu dionica i sl. Odvajanjem pravnog posla deponiranja od temeljnog ugovornog odnosa između stranaka javni bilježnik preuzima odgovornost samo u pogledu osnivanja javnobilježničkog pologa i postupanja po izričitim uputama stranaka, bez obveze provjere i potvrđivanja sadržaja temeljnog pravnog posla. Ugovorne strane u pravilu već neposredno nakon sklapanja temeljnog pravnog posla daju neposredni usmeni ili pisani nalog javnome bilježniku za osnivanje javnobilježničkog pologa u kojem postavljaju jasne i određene uvjete pod kojima će javni bilježnik kao neovisni i nepristrani povjerenik stranaka obaviti određene radnje i okončati javnobilježnički polog nakon što se ispune svi dogovoreni uvjeti.

11 Više o fiducijarnoj dužnosti u hrvatskom pravu društava vidjeti u: Jurić, Dionis: "Pravo manjinskih dioničara na podnošenje tužbe u ime dioničkog društva protiv članova uprave i nadzornog odbora", Zbornik Pravnog fakulteta Sveučilišta u Rijeci, Vol. 28., br. 1. (2007.), str. 541-586.

12 Zanimljiv je slučaj Sasidharan v. Piverger, 2016 NY Slip Op. 08387 pred Appellate Division, Second Department of New York, dostupno na https://law.justia.com/cases/new-york/appellate-divisionsecond-department/2016/2014-07065.html, 25. VIII. 2018. Sud je zaključio da escrow agent nema samo ugovorne dužnosti postupati po escrow agreementu, nego postaje osoba od najvišeg povjerenja svakoga tko ima određeni interes u tome da agent ne preda imovinu koju drži u pologu nikome osim pod uvjetima koji su izričito predviđeni u escrow agreementu. Iako je riječ o anglosaksonskom sustavu, presuda može biti određena smjernica oko tumačenja pojma povjerenik i kod javnobilježničkog pologa jer bi uloga escrow agenta trebala biti ista neovisno o osobi koja je obavlja.

13 Vidi presudu Webster v. Uslife Title Co., 123 Ariz. 130, 133 (Ariz. Ct. App. 1979), dostupno na: https://www.leagle.com/decision/1979253123ariz1301217, 25. VIII. 2018.

14 Vidi presudu Marathon U.S. Realties v. Kalb, 244 Ga. 390, 392 (260 S.E.2d 85) (1979). Slično i u presudi Berry v. McLeod, 124 Ariz. 346 (Ariz. 1979), dostupno na: https://law.justia.com/cases/arizona/ supreme-court/1979/14161-2.html, 24. VIII. 2018. U presudi se navodi obveza postupanja depozitara $\mathrm{s}$ najvišom razinom savjesnosti i vještinom (eng. perform the responsibilities with scrupulous honesty, skill).

15 Vidi presudu Roberts v. Porter, 193 Ga. App. 898, 900 (Ga. Ct. App. 1989), dostupno na https:// law.justia.com/cases/georgia/court-of-appeals/1989/a89a0856.html, 22. VIII. 2018.

16 Vidi presudu Schaefer v. Manufacturers Bank, 104 Cal. App. 3d 70, 77 (Cal. App. 2d Dist. 1980), dostupno na: https://law.justia.com/cases/california/court-of-appeal/3d/104/70.html, 25. VIII. 2018. 
Daljnje formalnosti oko načina čuvanja stvari u javnobilježničkom pologu detaljnije su propisane Javnobilježničkim poslovnikom ${ }^{17}$ i neće biti predmet razmatranja ovoga rada.

\section{PRAVNA NARAV JAVNOBILJEŽNIČKOG POLOGA}

\subsection{Javnobilježnički polog kao ostava}

Osnivanje javnobilježničkog pologa predstavlja, po mišljenju autora, specifičan neimenovani obveznopravni odnos stranaka s javnim bilježnikom sui generis koji u sebi sadrži značajke barem dvaju imenovanih ugovora iz ZOO-a: ugovora o ostavi i ugovora o nalogu, ${ }^{18}$ što će se pokušati i prikazati u nastavku. ${ }^{19}$ Autor ističe da bi se na javnobilježnički polog mogla primijeniti i pravila o drugim pravnim odnosima, ovisno od slučaja do slučaja, no da po svojoj naravi javnobilježnički polog uvijek sadrži barem bitna obilježja naloga i ostave.

Prema Zakonu o obveznim odnosima ${ }^{20}$ ugovorom o ostavi (depozitu) obvezuje se ostavoprimac (depozitar) da primi stvar od ostavodavca (deponenta), da je čuva i da je vrati kad je ovaj bude zatražio. Bitne sastojke ugovora o ostavi čine predmet ostave, trajanje ostave i naknada, kada je riječ o naplatnoj ostavi. ${ }^{21}$ Predmet ostave kod javnobilježničkog pologa uređen je odredbama čl. 109. i 110. ZJB-a kao lex specialis. Trajanje ostave stranke navode u zahtjevu za osnivanje javnobilježničkog pologa, a uobičajeno ovisi o nastupu određenog uvjeta ili roka. Prema autorima Klariću i Vedriću, ${ }^{22}$ ugovor o ostavi u pravilu je besplatan, iznimno naplatan kad je naknada ugovorena, i to kad se ostavoprimac profesionalno bavi čuvanjem stvari i kad to proizlazi iz okolnosti slučaja. Takav slučaj predstavlja javni bilježnik kao profesionalni depozitar stvari. Osim navedenoga, ugovor o ostavi je i jednostranoobvezni ugovor kada je besplatan, a dvostranoobvezni kada se daje naknada za čuvanje. Ujedno je neformalan i kauzalan (kauza je čuvanje stvari) pravni posao. Navedenim bitnim karakteristikama udovoljava javnobilježnički polog u cijelosti. ZOO propisuje da je ostavoprimac dužan vratiti stvar ostavodavcu čim je on zatraži. Kod instituta javnobilježničkog pologa vraćanje (ili predaja) stvari ovisno je o nastupu određenog uvjeta ili roka, odnosno o postupanju po određenom

17 Javnobilježnički poslovnik (Narodne novine br. 38/94, 82/94, 37/96, 151/05, 115/12 i 120/14).

18 Tako navodi Marčinko, Vladimir, Javnobilježnički polozi - depoziti, Javni bilježnik, br. 28. (2008)., str. 46.

19 Slično se navodi za Švicarsku u Silvio Grunder: Genügt der Escrow doch?, Gesselschafts und Kapitalmarktrecht, br. 04 (2016), str. 450.; opširnije o ugovoru o osnivanju pologa kao obveznopravnom ugovoru (escrow agreement-u) općenito vidi u: Stefan Gerster, Das Escrow Agreement als obligationenrechtlicher Vertrag, Schulthess Polygraph. Verl., Zürich, 1991.; Stefan Eisenhut, EscrowVerhältnisse - Das Escrow Agreement und ähnliche Sicherungsgeschäfte, Helbing \& Lichtenhahn, Basel, 2009.

20 Zakon o obveznim odnosima (Narodne novine br. 35/05, 41/08, 125/11, 78/15, 29/18), dalje: ZOO.

${ }^{21}$ Crnić, Ivica: Zakon o obveznim odnosima, Organizator, Zagreb, 2016., str. 1187.

22 Klarić, Petar, Vedrić, Mladen: Građansko pravo: Opći dio, stvarno pravo, obvezno i nasljedno pravo, Narodne novine, Zagreb, 2006., str. 544-545. 
nalogu stranaka (dostava dokumentacije, uplata cijene i sl.), a vraćanje je, ovisno o tome, moguće ostavodavcu ili trećoj osobi određenoj kao korisniku depozita (ostave).

Javnobilježnički polog po samome zakonu ima učinke sudskog pologa. Prema dijelu literature, na sudski se polog primjenjuju pravila o ugovoru o ostavi, iako je kod sudskog pologa riječ o jednostranom aktu javnopravnog značenja. ${ }^{23}$ Stoga bi se i na javnobilježnički polog, polazeći od takve pretpostavke, zbog slične naravi, prema mišljenju autora, na odgovarajući način mogla primijeniti pravila o ugovoru o ostavi.

Postoje dvojbena stajališta o karakteru ugovora o ostavi. Određena pravna literatura ugovor o ostavi karakterizira kao realan ugovor. Prema Klariću i Vedrišu, ${ }^{24}$ život i učinci ugovora o ostavi počinju tek s predajom stvari deponentu, a ne samim sklapanjem ugovora. To bi značilo da niti javni bilježnik nije vezan ugovornim odnosnom sa strankama prije nego što mu je stvar predana na čuvanje..$^{25}$ Slično o ugovoru o ostavi uređuju austrijsko i talijansko pravo. ${ }^{26}$ Prema suprotnom stajalištu, ugovor o ostavi predstavlja konsenzualan ugovor koji nastaje suglasnošću volja stranaka, a čin predaje predstavlja tek čin ispunjenja ugovora. ${ }^{27}$ Slično je uređeno u njemačkom i švicarskom pravu. ${ }^{28}$ Primjenom takvog stajališta na javnobilježnički polog, javni bilježnik preuzima obveze iz javnobilježničkog pologa vezane uz predmet pologa već samim osnivanjem javnobilježničkog pologa. Navodi se da je trenutnim zakonskim uređenjem ugovor o ostavi neodređeno opisan na način kao da predstavlja realni kontrakt, iako zapravo po svojoj naravi ipak pokazuje značajke konsenzualnog ugovora. ${ }^{29}$

$\mathrm{U}$ dijelu literature navodi se usporedba escrow agreementa s ugovorom o bankarskom novčanom pologu i polaganju vrijednosnih papira kada čine predmet polaganja. ${ }^{30}$ No, takva usporedba ne bi bila primjenjiva na javnobilježnički polog, s obzirom na to da se primjena odredbi ZOO-a u tom dijelu odnosi samo na banku kao depozitara, a ne i na javnog bilježnika za čije postupanje vrijede posebna pravila.

Osim odredbi ZOO-a o ugovoru ostavi kao lex generalis, na javnobilježnički polog primjenjuju se i posebne odredbe ZJB kao lex specialis o načinu čuvanju

23 Gorenc, Vilim, Belanić, Loris, Momčinović, Hrvoje, Perkušić, Ante, Pešutić, Andrea, Slakoper, Zvonimir, Vukelić, Mario, Vukmir, Branko, Komentar Zakona o obveznim odnosima, Narodne novine, Zagreb, 2014., str. 289.

24 Op. cit. u bilj. 21, str. 544.

25 U prilog tome vidi stajalište u presudi City of Fort Worth v. Pippen, 439 S.W.2d 660, 665 (Tex. 1969) dostupno na: https://law.justia.com/cases/texas/supreme-court/1969/b-1107-0.html, 26. VIII. 2018. Prema navedenoj presudi, odnos escrowa zasniva se kada escrow agent prihvati deponirani predmet, neovisno o postojanju escrow sporazuma. Slično i u presudi Boatright v. Tex. American Title Co., 790 S.W.2d 722 728 (Tex. App.—El Paso 1990), dostupno na: https://www.courtlistener.com/opinion/1577423/boatrightv-texas-american-title-co/, 25. VIII. 2018.

26 Op. cit. u bilj. 22, str. 1118.

27 Gl. ur. Gorenc, Vilim: Komentar Zakona o obveznim odnosima, Zagreb, 2005., RriF Plus, str. 1077.

28 Op. cit. u bilj. 22, str. 1119.

29 Op. cit. u bilj. 22, str. 1118-1119.

30 Op. cit. u bilj. 5, str. 505-506. 
preuzetih predmeta. Preuzeti novac, vrijednosne papire i dragocjenosti javni bilježnik je tako, sukladno čl. 111. ZJB-a, dužan čuvati odvojeno od svog novca i vrijednosnih papira, u posebnom omotu na koji će napisati predmet $\mathrm{i}$ ime stranke.

U pojedinim zemljama izričito se zabranjuje polaganje gotovog novca kod javnog bilježnika, no RH takvu odredbu nije ugradila u svoje zakonodavstvo. Javni bilježnik je obveznik postupanja po Zakonu o sprečavanju pranja novca i financiranja terorizma ${ }^{31}$ i primanje gotovine moguće je samo uz poštovanje strogih ograničenja postavljenih navedenim propisom. Posebno je u ZJB-u regulirano pitanje pologa novca, koji javni bilježnik može čuvati na posebnom računu kod banke ili druge financijske organizacije, što u praksi redovito i čini. Javni bilježnik otvara poseban račun za posebne namjene (trećih osoba) prema pravilima bankarskoga prava i na tom računu drži deponirana sredstva sve do isplate korisniku ili do vraćanja nalogodavcu ako se ne ispune svi predviđeni uvjeti za isplatu.

\subsection{Javnobilježnički polog kao nalog}

Osim značajki ugovora o ostavi, javnobilježnički polog kao instrument osiguranja plaćanja pokazuje i bitne značajke ugovora o nalogu. Kod osnivanja javnobilježničkog pologa, stranke predaju predmet javnom bilježniku na čuvanje kao neovisnom i nepristranom povjereniku koji ih čuva u njihovu zajedničkom interesu. Javni bilježnik pritom ne smije postupati suprotno nalogu stranaka, inače se izlaže obveznopravnoj odgovornosti za štetu. Stoga je bitno da upute sudionika dane javnom bilježniku budu jasne i nedvosmislene. Obveze i prava javnog bilježnika kao povjerenika stranaka i escrow agenta kod javnobilježničkog pologa nisu izričito propisani pozitivnim propisima i ovise samo o nalogu stranaka poštujući pritom načelo dispozitivnosti i prisilne propise. Nalozi javnom bilježniku se, prema mišljenju autora, mogu svoditi na sve oko čega su stranke suglasne, a posebice bi trebali uključivati jasno postavljene upute javnom bilježniku za npr. zaprimanje određene dokumentacije, izjava, predaju položene stvari trećoj osobi i sl. Po tim je nalozima javni bilježnik dužan postupati, na što se primjenjuju opće odredbe ZOO-a o ugovoru o nalogu kao lex generalis. Ograničenje je postavljeno odredbama ZJB-a kao lex specialis o postupanju javnih bilježnika, osobito čl. 111. st. 2. prema kojem će javni bilježnik deponirani novac i vrijednosne papire (zakonodavac ne spominje isprave i ostalo, op. a.) bez odgađanja predati vlasti ili osobi kojoj se imaju predati. Odredba se, po mišljenju autora, čini suvišnom jer bi i bez nje javni bilježnik predao predmete osobi kojoj se imaju predati. $\breve{C l}$. 112. ZJB-a propisuje postupanje javnog bilježnika u slučaju u kojem je nemoguće izvršiti naloženu predaju u određenom roku. Tada je javni bilježnik dužan po proteku roka ili, ako rok nije određen, najkasnije petnaest dana od dana preuzimanja, bez odlaganja vratiti stranci preuzete vrijednosti ili, ako to nije moguće, predati ih sudu na čuvanje i o tome obavijestiti predavatelja preporučenim pismom.

\footnotetext{
31 Zakon o sprečavanju pranja novca i financiranju terorizma (Narodne novine br. 108/17).
} 
Nalog javnom bilježniku u pravilu je sadržan već u neposrednom zahtjevu postavljenom javnom bilježniku ili u pismu koje pristigne javnom bilježniku (u pravilu zajednički pisani sporazum stranaka o osnivanju javnobilježničkog pologa). Za taj dio posla vrijede opća pravila propisana u ZOO-u o ugovoru o nalogu.

\section{OSNIVANJE JAVNOBILJEŽNIČKOG POLOGA}

Tumačenjem odredbi čl. 109-113. ZJB-a proizlazi da je od strane javnog bilježnika moguće fakultativno i obligatorno postupanje javnog bilježnika u preuzimanju na čuvanje, ovisno o vrsti predmeta deponiranja.

\subsection{Obveza javnog bilježnika na postupanje}

Obveza javnog bilježnika na postupanje kod osnivanja javnobilježničkog pologa razlikuje se ovisno o tome čine li predmet javnobilježničkog pologa: a) isprave ili b) novac, vrijednosni papiri i dragocjenosti.

U čl. 109. ZJB-a propisana je dužnost javnog bilježnika preuzeti na čuvanje isprave svih vrsta, a odbiti preuzimanje samo ako za to postoje opravdani razlozi. Zakon ne navodi koji su opravdani razlozi za odbijanje, no prilikom ocjene trebalo bi uzeti u obzir odredbe ZJB-a koje se odnose na opću službenu dužnost i uskratu službenih radnji javnog bilježnika.

U čl. 33. ZJB-a propisana je opća dužnost postupanja javnog bilježnika. Dužnost uskrate ${ }^{32}$ službene radnje predviđena je u slučaju kada je radnja nespojiva s njegovom službenom dužnošću, osobito ako se njegovo sudjelovanje zahtijeva radi postizanja očigledno nedopuštenog ili nedopuštenog cilja. Prema čl. 34. ZJB-a javni bilježnik ne smije bez valjanih razloga uskratiti poduzimanje službenih radnji. Javni bilježnik je ovlašten uskratiti obavljanje određene radnje u skladu s propisima koji uređuju obavljanje te radnje i zbog prezauzetosti. Također se u zakonu navodi da javni bilježnik ne smije poduzeti nikakvu službenu radnju s osobom za koju znade ili mora znati da je zbog malodobnosti ili zbog kojega drugoga zakonskog razloga nesposobna poduzeti ili sklopiti određeni pravni posao. Navedene odredbe ZJB-a mogle bi se tumačiti kao osnovni razlozi zbog kojih bi javni bilježnik bio ovlašten odbiti zasnovati javnobilježnički depozit stranaka.

O preuzimanju na čuvanje javni bilježnik će sastaviti zapisnik koji će potpisati osoba koja je predala ispravu i javni bilježnik, a u zapisniku će se posebno navesti, između ostaloga, oznaka položene isprave, razlog zbog kojega je položena i kome je treba izdati. Isprava se može javnom bilježniku, osim neposredno, poslati i poštom, o čemu se također sastavlja zapisnik, a potpis osobe koja je ispravu predala na tom

32 Više o dužnosti poduzimanja i uskratama službenih radnji javnog bilježnika vidi u: V. Prančić: "O dužnosti poduzimanja i uskrati službene radnje javnog bilježnika”, Zbornik Pravnog fakulteta u Zagrebu, Vol. 58, br. 4/2008, str. 997-1023. 
zapisniku nije potreban jer ga zamjenjuje zaprimljeno pismo. Autor zaključuje da bi pismo trebalo sadržavati i nalog stranaka po kojem javni bilježnik treba postupati, iako to zakon izričito ne navodi.

Obveza postupanja kod osnivanja javnobilježničkog pologa propisana je i u čl. 110. ZJB-a u slučaju kada javni bilježnik preuzima na čuvanje gotov novac, mjenice, čekove, javne obveznice i druge vrijednosne papire i dragocjenosti kad su mu u povodu sastavljanja javnobilježničkog akta ${ }^{33}$ predani zato da bi ih izručio stanovitoj osobi ili da bi ih položio kod određene vlasti. Ukoliko je već u javnobilježničkom aktu sadržan određeni nalog stranaka koji uključuje predaju navedenih predmeta određenim osobama ili vlasti, postoji obveza javnog bilježnika na postupanje. To je očekivano ako se vodi računa o tome da javni bilježnik već pri sastavljanju javnobilježničkog akta ili pri potvrđivanju privatne isprave provjerava jesu li ispunjeni svi zakonom traženi uvjeti. Bilo bi suprotno svrsi ovog instituta ako bi javni bilježnik nakon sastava javnobilježničkog akta ili potvrde privatne isprave odbio zasnovati javnobilježnički polog. Zapisnik o deponiranju javni je bilježnik dužan sastaviti samo ako preuzimanje predmeta nije potvrđeno u samome javnobilježničkom aktu u čijem je sastavljanju sudjelovao javni bilježnik, i tada zapisnik mora sadržavati bitne sastojke određene u čl. 110. st. 2. ZJB-a, uz obvezu izdavanja potvrde o deponiranju. Za slanje predmeta pismom također se sastavlja zapisnik kao i u slučaju deponiranja isprave.

\subsection{Ovlaštenje javnog bilježnika na uskratu preuzimanja na čuvanje predmeta}

U čl. 110. ZJB-a koji uređuje preuzimanje na čuvanje gotovog novca, mjenica, čekova, javnih obveznica i drugih vrijednosnih papira i dragocjenosti, određuje se mogućnost (bez obveze postupanja) javnog bilježnika za osnivanje javnobilježničkog depozita. Argumentum a contrario čl. 110. ZJB-a to bi bilo moguće u slučajevima kada se javnobilježnički polog ne zasniva u povodu sastavljanja javnobilježničkog akta. Ne navode se razlozi zbog kojih bi odbijanje bilo dopušteno, pa se može zaključiti da bi javni bilježnik po vlastitoj slobodnoj ocjeni mogao odlučiti hoće li ili neće zasnovati određeni javnobilježnički depozit novca, mjenica, čekova, javnih obveznica i drugih vrijednosnih papira i dragocjenosti sa strankama. Imajući u vidu s druge strane navedenu opću dužnost postupanja i uskrate službenih radnji javnog bilježnika, ova odredba, prema mišljenju autora, predstavlja iznimku od opće dužnosti postupanja. Na sadržaj zapisnika o deponiranju primjenjuju se odredbe koje se odnose na zapisnik u slučaju deponiranja gotovog novca, mjenica, čekova, javnih obveznica i drugih vrijednosnih papira i dragocjenosti u slučaju kada su javnom bilježniku predani u povodu sastavljanja javnobilježničkog akta zato da bi ih izručio stanovitoj osobi ili da bi ih položio kod određene vlasti.

33 Javnobilježnički akti su temeljem čl. 3. st. 1. ZJB-a vrsta javnobilježničkih isprava o pravnim poslovima i izjavama koje su sastavili javni bilježnici. Temeljem čl. 59. ZJB-a svojstvo javnobilježničkog akta dobivaju i potvrđene (solemnizirane) privatne isprave. 


\subsection{Osnivanje javnobilježničkog pologa - ugovorni odnos ili jednostrana službena radnja?}

ZJB ne propisuje izričito način na koji se zasniva javnobilježnički polog. Propisuje se samo obveza javnog bilježnika da sastavi zapisnik o preuzimanju na čuvanje predmeta. ${ }^{34}$

U okviru obrade teme ovoga rada postavlja se pitanje predstavlja li osnivanje javnobilježničkog pologa sklapanje posebnog ugovornog odnosa s javnim bilježnikom ili izvršavanje propisane opće službene dužnosti postupanja javnog bilježnika.

Prema dijelu domaće literature, polaganje dugovane stvari u sudski polog (čiji se učinci primjenjuju i na javnobilježnički polog) ne treba shvaćati kao ugovorni odnos između dužnika i suda kao depozitara, nego kao jednostrani sudski akt. S druge strane, polaganje kod druge zakonom ovlaštene osobe (javnom bilježniku, op. a.) u teoriji ima značajke ugovora o ostavi. ${ }^{35}$ Odgovor na pitanje predstavlja li osnivanje javnobilježničkog pologa uopće ugovorni odnos između javnog bilježnika i stranke, ili je riječ o poduzimanju jednostrane službene radnje na zahtjev stranke, pokušali su dati njemačka sudska praksa i teorija. Prevladavao je stav prema kojem je riječ o sklapanju privatnopravnog ugovora o deponiranju s javnim bilježnikom. U novije vrijeme prevladava stajalište da se kod osnivanja javnobilježničkog pologa radi o obvezi javnog bilježnika postupati u skladu sa svojom službenom dužnošću kao posebnim javnopravnim elementom svoje službe. ${ }^{36}$ Unatoč navedenom stavu, u Njemačkoj je trenutno važećim zakonom propisan prihvat prijedloga za osnivanje javnobilježničkog pologa od strane javnog bilježnika kao pretpostavka osnivanja pologa ${ }^{37}$ čime su i dalje, prema mišljenju autora, ostvareni elementi privatnopravnog ugovornog odnosa s javnim bilježnikom. Sastavljanje zapisnika o deponiranju pritom predstavlja samo konačnu radnju javnog bilježnika u postupku osnivanja pologa kao rezultat prihvata javnog bilježnika da sudjeluje u tome poslu. ${ }^{38}$

U Republici Hrvatskoj zakonodavac ne odgovara izričito na navedeno pitanje. S obzirom na to da mora postojati određeni jasno postavljeni nalog javnom bilježniku za postupanje, ${ }^{39}$ sadržan u usmenom ili pisanom zahtjevu stranke, postavlja se pitanje je li bitan uvjet osnivanja javnobilježničkog pologa i prihvat navedenog

34 Sukladno čl. 3. ZJB-a, javnobilježnički su zapisnici vrsta javnobilježničkih isprava o pravnim radnjama koje su obavili javni bilježnici ili kojima su bili nazočni.

35 Op. cit. u bilj. 22, str. 290.

36 Tako Milak, Filip: „Treuhand - javnobilježnički polog prema njemačkom pravu“, Javni bilježnik, Vol. XXI, br. 44. (2017.), str. 35.

37 Tako se navodi u op. cit. u bilj. 35, str. 38.

38 Par. 57. st. 5. Beurkundigungsgesetz (BeurG), (BGB1. I S. 1513, zadnje izmjene i dopune br. BGBl. I S. 2745).

39 Npr. u čl. 112. ZJB-a propisuje se nemogućnost javnog bilježnika da izvrši naloženu predaju. Argumentum a contrario potreban je nalog stranke. Isto tako, javni bilježnik općenito postupa temeljem zahtjeva stranke, usmenog ili pisanog. 
zahtjeva od strane javnog bilježnika ${ }^{40}$ ili je dovoljno samo postupanje u okviru obavljanja službene radnje predviđene ZJB-om.

Ako se polazi od pretpostavke da je riječ o privatnopravnom ugovornom odnosu koji ima značajke sklapanja ugovora javnog bilježnika sa strankom, postavlja se pitanje načina na koji bi taj odnos nastao. ZJB-om je propisana samo obveza javnog bilježnika na sastavljanje zapisnika o deponiranju, koji potpisuju i javni bilježnik i stranke, a zapisnik po zakonu ima svojstvo javne isprave. Prema dijelu literature, ,,ako nije odbio primiti nalog, nalogoprimac ga je prešutno prihvatio... i ugovor o nalogu je sklopljen... ${ }^{\text {“41 }}$ Prema tome stavu, javni bilježnik sastavljanjem i potpisom zapisnika potvrđuje novonastali pravni odnos u kojem je sudjelovao i prihvaća postavljene naloge stranaka onog sadržaja kojeg su uneseni u zapisnik. U suprotnom ne bi postupao nego bi odbio zasnovati javnobilježnički polog u skladu $\mathrm{s}$ gore navedenim ovlastima.

Ako se osoba javnog bilježnika, sukladno čl. 764. ZOO-a, podvede pod pojam osobe koja se po samome zakonu bavi deponiranjem isprava i novca, odnosno izvršavanjem postavljenih naloga stranaka, može se zaključiti i da je riječ o osobi koja se bavi obavljanjem tuđih poslova kao zanimanjem. Stoga je po samome zakonu dužna i odgovoriti na ponudu naloga stranke. Prema dijelu literature, ,obavljanjem tuđih poslova“" u smislu odredbe ZOO-a bave se npr. banke kod dokumentarnog inkasa, akreditiva ili bankarske garancije kada obavljaju poslove na koje se primjenjuju pravila ugovora o nalogu, odvjetnici i sl. ${ }^{42}$ a po svojim svojstvima mogli bismo u tu grupu podvesti i javne bilježnike u poslovima deponiranja kao povjerenike stranaka. Takvo tumačenje povlači i posljedice propisane navedenim člankom. Javni bilježnik je, ako ne želi prihvatiti ponuđeni nalog koji se odnosi na poslove deponiranja, prema mišljenju autora, dužan o tome bez odgađanja obavijestiti drugu stranu (nalogodavca), inače odgovara za štetu koja bi nastala po obveznopravnoj osnovi. Argumentum a contrario može se zaključiti da je javni bilježnik primanjem stvari na čuvanje i sastavljanjem zapisnika o deponiranju prihvatio ponudu stranke sadržanu u pismenom ili usmenom zahtjevu za osnivanje deponiranja. Potpisom zapisnika sklopljen je ugovor onog sadržaja koji je unesen u zapisnik. ${ }^{43}$ Prihvat, temeljem čl. 262. st. 2. ZOO-a, ne mora biti izričit, već se može i presumirati na temelju određene radnje koja se može smatrati prihvatom, pod što bismo mogli podvesti i sastavljanje i potpis zapisnika o deponiranju. Primjenom čl. 265. ZOO-a koji se odnosi na šutnju ponuđenika ugovor je sklopljen u trenutku kad je ponuda, odnosno nalog, pristigla ponuđeniku (u ovome slučaju javnom bilježniku). Samim time, javni bilježnik bi kao osoba u čiju poslovnu djelatnost potpada obavljanje tuđih poslova, aktivnom radnjom trebao odbiti ponuđeni mu nalog, jer u suprotnom

40 Nalog se mora prihvatiti da bi nastali učinci ugovora o nalogu. Tako u op. cit. u bilj. 21, str. 554.

${ }^{41}$ Op. cit. u bilj. 22, str. 1170.

42 Više o osobama koje su dužne odgovoriti na ponudu naloga vidi u: op. cit. u bilj. 22, str. 1124.

43 Tako se u prilog takvom stavu, npr. u presudi Commercial Escrow Co. v. Rockport Rebel, Inc., 778 S.W.2d 532 (Tex. App. Corpus Christi 1989) navodi da escrow agent koji postupa suprotno escrow sporazumu može biti pozvan na odgovornost zbog kršenja ugovora, dostupno na: https://www.leagle.com/ decision/19891310778sw2d53211252, 27. VIII. 2018. 
preuzima obvezu naloženog mu postupanja. Stoga bi, prema odredbama ZJB-a, već sama predaja stvari na čuvanje javnom bilježniku predstavljala radnju osnivanja javnobilježničkog depozita sa strankom što bi se u zapisniku kao javnoj ispravi koju javni bilježnik i stranke potpisuju samo evidentiralo.

S druge strane, ukoliko se polazi od pretpostavke da je deponiranje predmeta obavljanje službene dužnosti javnog bilježnika, kao što tumači dio autora u Njemačkoj, tada bi se osnivanje i potpis zapisnika o deponiranju moglo tumačiti kao jednu od zakonom predviđenih radnji u postupku osnivanja depozita, čija osnova proizlazi iz samog zakona. Takvo tumačenje moglo bi se argumentirati već iznesenim javnopravnim elementom javnobilježničke službe kao javne službe. ${ }^{44}$ Iz toga proizlazi i opća dužnost postupanja javnog bilježnika kao osobe javnog povjerenja i izvršenja službene radnje na zahtjev stranke osim u iznimno propisanim slučajevima. U prilog se tome može iznijeti i argument da su zbog uskrate službene radnje strankama na raspolaganju i određena pravna sredstva pred sudom predviđena u ZJB-u ${ }^{45}$ što dodatno govori da je riječ o izvršenju službene radnje, tj. posla s uključenim posebnim javnopravnim elementom.

Mišljenje je autora, nakon svega navedenoga, da je javnobilježnički polog institut mještovite naravi koji pokazuje elemente i privatnopravnog ugovornog odnosa stranaka s javnim bilježnikom u kojem mora postojati jasno postavljeni nalog stranaka s elementima ostave, ali je istovremeno riječ o odnosu koji u sebi sadrži javnopravne elemente javnobilježničke službe jer je obuhvaćen obvezom obavljanja službene dužnosti na zahtjev stranke. Posljedično, u slučaju eventualnog kršenja pravila iz takvog odnosa primjenjivale bi se odredbe obveznog prava u onom dijelu koji se odnosi na ugovorne elemente javnobilježničkog pologa, a pravila Zakona o javnom bilježništvu u dijelu koji se odnosi na obavljanje službene dužnosti javnog bilježnika, sadržaj zapisnika i sl. Pritom, ako prihvatimo takvo tumačenje, osnivanje javnobilježničkog pologa, prema mišljenju autora, pokazuje i određene značajke instituta obveznog sklapanja ugovora iz ZOO-a u slučajevima kada je takvo obvezno postupanje propisano u ZJB-u kao lex specialis. Zapisnik bi, prema tome, predstavljao samo dokaz o sklopljenom pravnom poslu u kojem je javni bilježnik sudjelovao prihvaćajući zahtjev stranaka sadržan u zapisniku koji ima svojstvo javne isprave.

44 Čl. 1. ZJB-a.

45 Opširnije o mogućnostima javnog bilježnika za uskratu službene radnje vidi u op. cit. u bilj. 8, str. 1019-1021. 


\subsection{Komparativni prikaz}

U Sloveniji se pitanje osnivanja javnobilježničkog pologa uređuje Zakonom o notariatu $\mathrm{u}^{46} \mathrm{u}$ okviru petog odjeljka (slov. prevzemanje listin, denarja in vrednostnih papirjev v hrambo in izročitev) u čl. 87-92. Sadržajno slovenski zakon regulira javnobilježnički polog na način kao u Republici Hrvatskoj. Komparacijom zakonskog teksta ne dolazi se do zaključka da postoje bitne razlike u načinu osnivanja, pa se jezičnim tumačenjem slovenskog propisa ne može dobiti ni izričiti odgovor o načinu osnivanja i pravnoj naravi javnobilježničkog pologa.

Srbija, s druge strane, detaljno uređuje institut javnobilježničkog depozita (srb. javnobeležnički depozit) u čl. 165-175. Zakona o javnom beležništvu. ${ }^{47}$ Pojam predmeta koji se mogu deponirati u čl. 165. široko je opisan. ${ }^{48}$ Razlikuje se obvezno i fakultativno preuzimanje na čuvanje. Dužnost javnog bilježnika na osnivanje javnobilježničkog pologa propisana je samo kod depozita predmeta u slučajevima kad je zakonom određeno da dužnik može položiti stvar koju duguje kod suda ili kod javnog bilježnika kao povjerenika (kao način ispunjenja obveze). U ostalim slučajevima postoji samo mogućnost javnog bilježnika da zasnuje javnobilježnički depozit predmeta, za što je potrebno ispuniti određene zakonom propisane pretpostavke. Za osnivanje javnobilježničkog pologa deponent je dužan popuniti obrazac prijedloga za javnobilježnički polog čiji je sadržaj detaljno propisan u čl. 167. Zakona o javnom beležništvu. ${ }^{49} \mathrm{O}$ prihvaćanju prijedloga ${ }^{50}$ javni bilježnik izdaje posebnu potvrdu. Sadržaj potvrde propisan je u čl. 167. st. 2. Zakona o javnom beležništvu, i kao takav istovjetan je sadržaju iz obrasca prijedloga deponenta. U čl. 168. Zakona o javnom beležništvu propisano je da javni bilježnik može odbiti deponiranje predmeta ako ocijeni da nisu ispunjeni uvjeti za primanje predmeta u depozit zbog dimenzija ili svojstava predmeta ili ako predmet predstavlja izvor opasnosti za okolinu ili ako deponent prije ostavljanja predmeta u depozit ne predujmi troškove čuvanja ili ako je deponiranje predmeta u javnobilježnički

46 Zakon o notariatu (pročišćeni tekst - Uradni list RS, br. 2/07, 45/08, 91/13, dalje: Zakon o notariatu). U čl. 2. općenito je propisano da javni bilježnik, između ostaloga, preuzima na čuvanje isprave, novac i vrijednosne papire radi predaje trećim osobama ili državnim tijelima.

47 Zakon o javnom beležništvu (Sl. glasnik RS, br. 31/2011, 85/2012, 19/2013, 55/2014 - dr. zakon, 93/2014 - dr. zakon, 121/2014, 6/2015 i 106/2015).

48 Kao mogući predmeti javnobilježničkog depozita navode se novac, vrijednosni papyri, osim serijskih i onih u nematerijaliziranom obliku, druge isprave koje se mogu unovčiti, isprave koje se ne mogu unovčiti, spisi, rukopisi, zapisi, osobne arhive, dokumenti, odlikovanja, umjetnički predmeti, plemeniti metali, nakit, dragocjenosti i drugi predmeti izrađeni od plemenitih metala, kada to zakonom nije zabranjeno.

49 Između ostaloga, traži se navođenje zahtjeva za deponiranje predmeta, razloga zbog kojih se predmet deponira, oznake vrijednosti predmeta, vrijeme za koje se predmet ostavlja na čuvanje ili izjava da se predmet može preuzeti po viđenju (u slučaju kada se depozit zasniva u korist osobe koja je predmet i predala, op. a.), podaci o osobi u čiju se korist predmet deponira, osim ako je riječ o samome deponentu, način postupanja s novcem odnosno ispravama od vrijednosti i sl.

50 Vezano uz način postupanja s novcem, stranka određuje hoće li javni bilježnik čuvati novac u javnobilježničkom depozitu ili će ga uložiti u banku i pod kojim uvjetima, a ako su predmet depozita strana valuta i devize, postupa u skladu s propisima koji uređuju devizno poslovanje. Kod depozita isprava koje imaju vrijednost, stranka određuje hoće li ovlastiti javnog bilježnika za poduzimanje radnji radi očuvanja, osiguranja ili namirenja prava iz isprave. U tom slučaju javni bilježnik ima ovlast punomoćnika. 
depozit zakonom zabranjeno. Zakon detaljno uređuje i pitanje čuvanja položenog predmeta te predaje strankama. ${ }^{51}$

Na razini Bosne i Hercegovine, institut javnobilježničkog pologa uređen je zasebno za područje Federacije $\mathrm{BiH}$, za područje Republike Srpske i za područje Distrikta Brčko, sličnim pravilima kao i u RH. ${ }^{52}$ Osnivanje javnobilježničkog pologa u Federaciji BiH uređeno je Zakonom o notarima ${ }^{53}$ u čl. 111-114. Sadržajno gotovo identično odgovara odredbama našeg ZJB-a. Osnivanje javnobilježničkog pologa, kao i u našem pravu, ima učinke sudskog pologa. U Republici Srpskoj javnobilježnički depozit uređen je u čl. 107-110. Zakona o notarima. ${ }^{54} \mathrm{U}$ ovome pravnom propisu javnobilježnički depozit uređen je na istovjetan način kao i u Republici Hrvatskoj. Za područje Distrikta Brčko na snazi je Zakon o notarima, ${ }^{55}$ u kojem se na javnobilježnički depozit primjenjuju odredbe čl. 85-88, istovjetne onima koje su implementirane u našem ZJB-u.

Uzimamo kao drugačiji primjer Estoniju kao državu u kojoj su javnobilježnički polog i njegovo osnivanje obrađeni na drugačiji način njihovim Zakonom o bilježništvu ${ }^{56} \mathrm{u}$ §35. Deponiranje je službena dužnost koja prati određeni pravni posao ako je u njemu sudjelovao javni bilježnik i ako osoba koja zahtijeva depozit ima legitimni interes koji proizlazi iz transakcije čije se provođenje osigurava osnivanjem depozita. Estonski zakon izričito navodi da temelj depozita čini autentificirana prijava osobe koja traži osnivanje depozita, osim u slučaju kada je zahtjev (nalog) već sadržan u samom javnobilježničkom aktu osnovnog posla u kojem sudjeluje javni bilježnik. Propisano je da je deponiranje imovine moguće i dopušteno samo radi predaje predviđenom korisniku ili trećoj označenoj osobi

51 Prema čl. 171., javni je bilježnik dužan predati deponirane predmete deponentu ili osobi u čiju je korist deponiranje izvršeno (ovisno o tome kako je navedeno u prijedlogu odnosno potvrdi, op. a.) nakon što mu deponent ili korisnik predaju javnobilježničku potvrdu o deponiranju i nadoknade troškove čuvanja stvari ako ti troškovi prelaze iznos već uplaćenih troškova. Ako javni bilježnik odbije predati predmet, deponent ili korisnik depozita mogu o tome podnijeti žalbu Komori. Neobična je odredba prema kojoj deponent ili korisnik depozita mogu predmet podići prije isteka vremena na koje je deponiranje zasnovano. Prema doslovnom tumačenju, nema ograničenja da to učini bilo koja od strana, neovisno o ispunjenju traženih uvjeta, što nije u skladu sa svrhom instituta javnobilježničkog pologa, kod kojega obje stranke nastupaju s punim povjerenjem u javnog bilježnika kao osobe koja će svoje naložene obveze ispuniti samo kada su neupitno ispunjeni traženi uvjeti. Zanimljivo je da prema čl. 172. javni bilježnik poziva korisnika depozita da nakon isteka roka preuzme predmet. U Republici Hrvatskoj u pravilu javni bilježnik traži da stranke same određenim izjavama potvrde ispunjenje uvjeta i samim time traže povrat predmeta, otklanjajući od sebe odgovornost. Javni bilježnik će tražiti od deponenta da se u određenom roku izjasni hoće li depozit nastaviti, hoće li promijeniti korisnika depozita ili će preuzeti predmet. Ako nitko ne preuzme deponirani predmet, javni bilježnik ga je, sukladno čl. 173., dužan čuvati jednu godinu od primitka obavijesti strankama, i nakon toga obavijestiti nadležni sud, te ga potom predati zakonom određenom tijelu ili prodati po ovlaštenju suda.

52 Općenito o notarskoj službi u BiH vidi: Povlakić, Meliha: „Nadležnost notara u Bosni i Hercegovini“, Zbornik PFZ, Vol. 63, br. 2 (2013.), str. 245-310.

53 Zakon o notarima (Službene novine Federacije BiH, br. 45/02).

54 Zakon o notarima (Službeni glasnik Republike Srpske, br. 86/04, 2/05, 74/05, 76/05, 91/06, 37/07, 50/10, 78/11, 20/14, 68/17).

55 Zakon o notarima (Službeni glasnik Brčko Distrikta BiH, br. 09/03, 17/06).

56 Notariaadiseadus (RTI 2000, 104, 684 zadnja izmjena RT I, 9. X. 2013., 1), engleski prijevod (eng. Notaries Act) u službenom glasniku Republike Estonije, dostupno na: https://www.riigiteataja.ee/ en/eli/511112013002/consolide, 26. VIII. 2018. 
ili samome deponentu. Javni bilježnik je dužan odbiti zasnovati depozit ako se raspolaganjem krše prava osobe koja se nalazi u osnovnom transakcijskom pravnom odnosu ili nekog trećeg. Može se zaključiti da Estonija u svom zakonu u dijelu osnivanja javnobilježničkog pologa predviđa odnos koji bi se mogao tumačiti isključivo kao službena radnja javnog bilježnika na temelju prijave stranaka ili klauzule sadržane u pravnom poslu u kojem je sudjelovao javni bilježnik.

Ukratko se u nastavku navodi i primjer Rusije u kojoj pitanje osnivanja javnobilježničkog pologa donedavno nije bilo detaljnije uređeno. ${ }^{57}$ Prema ruskom Osnovnom zakonu o javnom bilježništvu, ${ }^{58}$ javnobilježnički polog uređen je u čl. 87. i 88. (Odjeljak XV.), u kojima se općenito navodi ovlast javnog bilježnika na preuzimanje novca i vrijednosnica u depozit (rus. prinyatie $v$ depozit denezhnyh summ $i$ cennyh bumag) od dužnika kako bi ih predao vjerovniku, ali samo u slučajevima propisanima ruskim građanskim pravom. ${ }^{59}$ Osnivanje javnobilježničkog pologa prema navedenom uređenju u Rusiji donedavno je bilo restriktivno uređeno i to samo u okviru instituta predviđenih građanskim pravom. Učinak je polaganja novca i drugih vrijednosti bio prestanak obveze dužnika. ${ }^{60}$

Novim izmjenama i dopunama više relevantnih propisa ${ }^{61}$ koje su stupile na snagu 1. lipnja 2018. godine otvorena su vrata širem korištenju depozitne funkcije javnog bilježnika i u drugim slučajevima i u ostalim transakcijama, izvan gore navedenih predviđenim građanskim pravom, čime se očekuje i veća uloga javnih bilježnika kao depozitara. Dopunjen je čl. 87. Osnovnog zakona o javnom bilježništvu novim stavcima i Ruska federalna javnobilježnička komora (rus. Federalınas notarialınaя palata) izdala je posebno pismo vezano uz najnovije izmjene ${ }^{62}$ u kojem se navode

57 Više o ruskom notarijatu vidi u: Dabić, Ljubiša; ,Javno beležništvo u Ruskoj Federaciji“, Strani pravni život, 2000., br. 1-3, str. 117-134.

58 Rus. Osnovy zakonodatel'stva Rossijskij Federacii o notariate (Br. 4462/1 od 11. II. 1993., zadnje izmjene i dopune br. 194-FZ od 3. VIII. 2018.), korišten neslužbeni pročišćeni tekst dostupan na: http:// base.garant.ru/10102426/, 25. VIII. 2018.

59 Slučajevi su navedeni u čl. 327. ruskog Građanskog kodeksa (rus. Graždanskiǔ kodeks Rossiǔskoǔ Federacii, prvi dio br. FZ-51 od 30. XI. 1994., drugi dio br. FZ-14 od 26. I. 1996., treći dio br. FZ146 od 26. XI.2001., četvrti dio br. FZ-230 od 18. XII. 2006., zadnje izmjene $i$ dopune br. FZ-339 od 3. VIII. 2018.), neslužbeni pročišćeni tekst dostupan na http://base.garant.ru/10164072/, 25. VIII. 2018. Dužnik ima pravo položiti novac ili vrijednosne papire u polog kod javnog bilježnika ili suda ako ne može ispuniti obvezu kada su vjerovnik ili osoba ovlaštena za primitak dugovanoga nepoznate, ako je vjerovnik poslovno neposoban a nema određenog zastupnika, ako je očito neizvjesno tko je vjeronik, osobito kada je u tijeku sudski spor između dužnika i više osoba ili kad vjerovnik odbija primiti dugovanu činidbu ili drugo odgađanje primitka od strane vjerovnika. Polaganjem novca ili drugih vrijednosti u polog dužnikova obveza prestaje, a javni bilježnik o tome je dužan obavijestiti sud.

60 Vraćanje novca i isprava osobi koja ih je deponirala moguće je samo uz pisanu suglasnost osobe u čiju je korist plaćanje odnosno deponiranje zasnovano ili po odluci suda.

${ }_{61}$ Savezni zakon o izmjenama i dopunama prvog i drugog dijela Građanskog kodeksa i povezanih zakonodavnih akata Ruske Federacije (rus. Federal'nyj zakon o vnesenii izmenenij v časti pervuju $i$ vtoruju Graždanskogo kodeksa Rossijskoj Federacii i otdel'nye zakonodatel'nye akty Rossijskoj Federacii) (br. 212-FZ od 26. srpnja 2017. godine, stupio na snagu 1. lipnja 2018. g.), dostupno na: http://base.garant. ru/71730254/, 25. VIII. 2018.

62 Pismo br. 3041/03-16-3 Federalne javnobilježničke komore Ruske Federacije od 20. VI. 2018. godine (rus. Pis'mo Federal'noj notarial'noj palaty ot 20 ijunja 2018 g. N 3041/03-16-3 “O dogovore uslovnogo deponirovanija (èskrou) i dogovore publičnogo depozitnogo sčeta”), dostupno na: http://base. garant.ru/71975714/, 25. VIII. 2018. 
bitni uvjeti pod kojima će javni bilježnici postupati u navedenim transakcijama. Prema dopunjenom čl. 87. zakona (i Pismu koje pritom samo detaljnije obrazlaže zakonske izmjene), javni bilježnik je ovlašten primati sredstva u depozit, za što je dužan otvoriti poseban račun (rus. publičnbiǔ depozitnbiǔ sčet). ${ }^{63}$ Što se tiče načina osnivanja javnobilježničkog pologa, u čl. 88.1. navodi se da se zasniva na temelju zajedničke izjave stranaka sadržane u prijedlogu podnesenom javnom bilježniku s jasno određenim nalozima. Također se izričito navodi da se, iako javni bilježnik izvršava određene radnje predviđene ugovorom, ne smatra strankom samog ugovora. Nadalje se navode odredbe o postupanju javnog bilježnika ovisno o tome prima li u depozit gotovinu ili bezgotovinsku uplatu na račun. ${ }^{64}$

U Njemačkoj je javnobilježnički polog detaljno uređen Saveznim zakonom o bilježništvu ${ }^{65}$ i Zakonom o potvrđivanju i sastavljanju isprava ${ }^{66}$ Sadržaj se navodi samo u mjeri u kojoj su vidljive specifičnosti vezane uz osnivanje pologa i njegove učinke. U §23 Saveznog zakona o bilježništvu općenito se navodi da su bilježnici odgovorni za preuzimanje na čuvanje novca, vrijednosnih papira i ostalih dragocjenosti koje im stranke daju na čuvanje ili za dostavu trećim stranama. Detaljnije uređenje javnobilježničkog pologa nalazi se u šestom odjeljku, §57-62. Zakona o potvrđivanju i sastavljanju isprava. ${ }^{67}$ Preuzimanje na čuvanje dopušteno je pod uvjetima da postoji pravni interes za osiguranjem (plaćanja, op. a) osoba uključenih u određeni pravni odnos, postojanje upute stranaka propisanog sadržaja iz koje su vidljive dužnosti bilježnika, da je bilježnik prihvatio prijedlog za osnivanje i da se osnivanjem javnobilježničkog pologa ispunjuje svrha iz osnovnog posla. Zakonodavac tako za osnivanje javnobilježničkog pologa razlikuje prijedlog za osnivanje (njem. Verwahrungsantrag) i uputu stranke (njem. Verwahrungsanweisung) za postupanjem (moglo bi se okarakterizirati kao nalog, op. a.). Oba dokumenta nužna su za osnivanje javnobilježničkog pologa. Javni bilježnik nije dužan prihvatiti prijedlog stranke, ali prihvat je jedan od propisanih uvjeta osnivanja pologa, ${ }^{68}$ što mu nedvojebeno daje ugovornu narav u kontekstu razmatranja iz ovoga rada. Prema $\$ 57$ BeurkG, uvjeti koje provjerava javni bilježnik prilikom osnivanja pologa, osim prihvata ponude, još su i: pravni interes za osiguranjem, uputa zakonom propisanog sadržaja i svojstvo upute da se njome ostvaruje zakonom propisana svrha. Materija je u njemačkoj pravnoj literaturi

63 Javni bilježnici moći će zasnivati javnobilježničke pologe čiji predmet mogu biti pokretine (gotovinski novac, vrijednosni papiri i isprave), nenovčana sredstva i sl. Dužnost je javnih bilježnika provjeriti jesu li ispunjeni svi uvjeti za predaju deponiranih predmeta korisniku depozita, npr. nastup roka predviđenog ugovorom, nastup događaja predviđenog ugovorom, izvršavanje određenih radnji od strane korisnika depozita ili nekog trećeg. Također se propisuju pravila o posebnom depozitnom računu javnog bilježnika za posebne namjene. Trajanje depozita ne smije biti zasnovano na period duži od 5 godina.

64 Gotovinski novac javni je bilježnik dužan položiti na poseban račun u roku od najkasnije 1 dan od dana primitka. Ukoliko novac bude na depozitnom računu javnog bilježnika duže od deset godina od dana deponiranja bez potraživanja ijedne od strana, javni bilježnik je dužan sredstva proslijediti u trezor Ruske Federacije (rus. v kaznu Rossiŭskoŭ Federacii).

65 Bundesnotarordnung (BNotO), (BGB1. I S. 97, zadnje izmjene i dopune br. BGB1. I S. 3618).

66 BeurkG (op. cit. u bilj. 37.).

67 Javnom bilježniku zabranjeno je novac preuzeti na čuvanje.

$68 § 57$. BeurkG. 
vrlo detaljno obrađena ${ }^{69}$ i može poslužiti kao uzor prilikom reguliranja pitanja javnobilježničkog pologa i u našem pravu.

\section{PRAVNI UČINCI OSNIVANJA JAVNOBILJEŽNIČKOG POLOGA}

\section{Prema čl. 113. ZJB-a javnobilježnički polog ima učinak sudskoga pologa. ${ }^{70}$}

Sudski polog moguće je zasnovati iz razloga navedenih u čl. 186. st. 1. ZOO-a. ${ }^{71}$ Dužnik je ovlašten položiti dugovanu stvar kod suda ili kod za to zakonom ovlaštene osobe $^{72}$ (i javnog bilježnika, o. a.).Za osnivanje sudskog pologa ne postoje jedinstvena pravila, već je osnivanje uređeno pravilima izvanparničnog postupka. ${ }^{73}$ Postupovne odredbe o tome valja tražiti u Zakonu o izvanparničnom postupku, ${ }^{74} \mathrm{u}$ kojem nema posebne odredbe koja bi se odnosila na sudski polog, već je potrebno temeljem čl. 21. st. 1. Zakona o vanparničnom postupku primjenjivati opće odredbe građanskog procesnog prava.$^{75}$ Opća je odredba o sudskom pologu propisana i čl. 138. Zakona o sudovima, no samo ograničeno. ${ }^{76}$ Iznos pristojbe koji se plaća za osnivanje sudskog pologa propisan je Zakonom o sudskim pristojbama. ${ }^{77}$ Za osnivanje sudskog pologa sud donosi posebno rješenje u izvanparničnom postupku. ${ }^{78}$ Sud ne smije uskratiti dužniku polaganje dugovane stvari ako dužnik za osnivanje pologa navede neki od razloga taksativno pobrojanih u čl. 327. ZOO-a. ${ }^{79}$

69 Više o javnobilježničkom pologu u Njemačkoj vidi u knjizi: Armbrüster, Christian, Preuß, Nicola, Renner, Thomas: Beurkundungsgesetz und Dienstordnung für Notarinnen und Notare - Kommentar, 7. izdanje, Deutscher Notarverlag GmbH \& Co. KG Fachverlag für Notare, Bonn, 2015.; DannenbergMletzko, Lena; Baumgärtner-Wrede, Gerhard: Notariatskunde-Sicher in der Prüfung, erfolgreich in der Praxis, 3. izdanje, Gabler, Wiesbaden, 2005.; Milak, Filip: „Treuhand - javnobilježnički polog prema njemačkom pravu“, Javni bilježnik, Vol. XXI, br. 44. (2017.), str. 33-45.

70 Više o tome vidi u op. cit. u bilj. 22, str. 288-290.

71 Radi se o slučajevima kada je vjerovnik u zakašnjenju ili je nepoznat, ili kad je neizvjesno tko je vjerovnik, ili gdje se nalazi, ili kad je vjerovnik poslovno nesposoban, a nema zastupnika, dužnik ili treća osoba koja ima pravni interes da obveza bude ispunjena.

72 Više o sudskom pologu kao načinu ispunjenja obveze vidi u: Momčinović, Hrvoje: „Zakašnjenje vjerovnika“, Zbornik PFZ, Vol. 58, br. 1-2 (2008.), str. 300-304.

73 Više o učincima sudskog pologa i primjeni izvanparničnog prava s primjerima vidi U: Maganić, Aleksandra, Šago, Dinka, Jurić, Ana, Vrljić, Darko: Izvanparnično pravo s komentarom, primjerima obrazaca za praktičnu primjenu, sudskom praksom, bilješkama i zbirkom propisa, Vizura, Zagreb, 2015., str. 795-805.

74 Zakon o vanparničnom postupku (Službene novine Kraljevine Jugoslavije br. 45/34, preuzet Zakonom o načinu primjene pravnih propisa donesenih prije 6. travnja 1941. (Narodne novine br. 73/91)).

75 U čl. 21. st. 1. Zakona o vanparničnom postupku navodi se: „Ukoliko ovaj zakon nema posebnih naređenja, u ovom postupku će se, i pored slučajeva posebice navedenih u ovom zakonu, shodno primenjivati propisi Građanskog parničnog postupka“.

76 Sudski polog obrađen je odredbom čl. 138. Zakona o sudovima, ali samo u dijelu koji se odnosi na nepreuzimanje sudskog pologa u roku koji je predviđen. Prema čl. 144. istog zakona, na sudske pologe osnovane do dana stupanja na snagu ovog zakona primjenjivat će se odredbe navedenog članka 138.

77 Zakon o sudskim pristojbama (Narodne novine br. 74/95, 57/96, 137/02, 26/03, 125/11, 112/12, 157/13, 110/15).

78 Vidi op. cit. u bilj. 72, str. 798., 802-804.

79 Tako se navodi u: op. cit. u bilj. 72, str. 797. 
Učinak sudskog pologa u obveznopravnim odnosima reguliran je u čl. 190. st. 1. ZOO-a, prema kojem polaganje dugovane stvari oslobađa obveze već u trenutku polaganja stvari, i od trenutka polaganja prestaju teći kamate. Ako je dužnik bio u zakašnjenju, njegovo zakašnjenje prestaje. Od trenutka kad je stvar položena rizik slučajne propasti ili oštećenja stvari prelazi na vjerovnika. Ako dužnik uzme natrag položenu stvar, smatra se da nije bilo polaganja.

Strankama je u praksi prvenstveno cilj osigurati se na način da se neutralizira rizik neplaćanja odnosno neispunjenja obveza, za što ovlašćuju javnog bilježnika kao svog posebnog neovisnog i nepristranog povjerenika. Obveznopravni učinci sudskog pologa primjenjuju se ex lege i na stranke kada koriste depozitnu funkciju javnog bilježnika kao način ispunjenja obveze ili sredstvo osiguranja plaćanja. Funkcija javnog bilježnika kod poslova deponiranja, prema mišljenju autora, trebala bi imati dvostruki karakter. S jedne strane, javnopravna funkcija dolazi posebno do izražaja u slučaju kada depozit predstavlja način ispunjenja obveze sukladno ZOO-u kada mu je i funkcija depozitara izjednačena sa sudom. No, s druge strane, u ostalim slučajevima (npr. deponiranje kod kupoprodaje nekretnine ili poslovnih udjela u trgovačkom društvu) bila bi riječ o strogo privatnopravnom ugovornom odnosu u kojem javni bilježnik obavlja funkciju escrow agenta sa širim dispozitivnim ovlastima od onih određenih u Zakonu o obveznin odnosima.

U Sloveniji Zakon o notariatu propisuje da javnobilježnički polog nema učinke sudskog pologa, što je suprotno našem uređenju. Time se zapravo odvaja depozitna funkcija javnog bilježnika u odnosu na onu koju predstavlja sud. Polaganje u sudski polog predviđeno je samo kao građanskopravni institut u okviru čl. 302-310. slovenskog Obligacijskog zakonika.

\section{ZAKLJUČAK}

U današnje doba razvijenih gospodarskih odnosa praćenih mnogobrojnim rizicima, od kojih je jedan od važnijih svakako naplata isporučene robe, sudionici primjenjuju razne instrumente osiguranja plaćanja ovisno o karakteristikama odnosa u koje ulaze radi smanjenja tih rizika. Na raspolaganju sudionicima u domaćim i međunarodnim plaćanjima uobičajeno stoje različite vrste dokumentarnih akreditiva, bankarske garancije, escrow računi i, između ostaloga, institut javnobilježničkog pologa. Iako u praksi češće korišten u svrhu osiguranja plaćanja i drugih obveza kod kupoprodaje nekretnina, učestalo je korištenje javnobilježničkog pologa kao načina osiguranja plaćanja i za transkakcije veće vrijednosti koje se obavljaju između trgovaca.

Zbog strogih zakonskih odredaba koje se odnose na postupanje javnog bilježnika kao neovisnog i nepristranog povjerenika stranaka, ova se vrsta instituta može smatrati vrlo pouzdanim instrumentom osiguranja plaćanja.

Ipak, sudska je praksa po pitanju javnobilježničkog pologa u Republici Hrvatskoj još uvijek nedovoljno razvijena i svodi se prvenstveno na učinke javnog bilježnika 
kao depozitara u slučajevima predviđenima u ZOO-u kao načina ispunjenja obveze dužnika. Ne daje se odgovor na pitanja poput npr. pravne naravi javnobilježničkog pologa, načina njegova osnivanja i sl. pa stranke ne mogu sa sigurnošću znati koja će se pravila primjenjivati u slučaju kada koriste javnobilježnički polog kao instrument osiguranja plaćanja. Javnobilježnički polog uređen je nacionalnim zakonodavstvom svake zemlje zasebno, bez međunarodnih dokumenata, što bi se moglo protumačiti kao jedan od razloga koji sudionike međunarodnih ugovornih odnosa odvlači od učestalijeg korištenja ovog instrumenta osiguranja plaćanja u praksi.

Važeći tekst ZJB-a u dijelu javnobilježničkog pologa nedorečen je i nepotpun (uređuje polog sa samo nekoliko zakonskih članaka, bez odgovora na pitanja koja se postavljaju u radu) i neprilagođen situacijama u kojima polog služi isključivo kao sredstvo osiguranja plaćanja. Pritom se zanemaruje mješovita funkcija javnog bilježnika prilikom osnivanja javnobilježničkog pologa, i to ona u kojoj javni bilježnik pri osnivanju javnobilježničkog pologa s jedne strane obavlja službene radnje s javnopravnim elementima s učincima temeljem čl. 190. ZOO-a i s druge strane uloga javnog bilježnika kao sudionika privatnopravnog odnosa sa strankom.

Tumačenjem komparativnih rješenja također se izričito ne može dobiti odgovor na pitanje o pravnoj naravi javnobilježničkog pologa, iako neke od njih puno detaljnije reguliraju navedenu materiju. Bilo bi preporučljivo de lege ferenda propisati obvezu stranaka da prvo podnesu ponudu/zahtjev javnom bilježniku za osnivanje javnobilježničkog pologa i uvjetovati osnivanje pologa prihvatom javnog bilježnika, kao što se to čini npr. u Njemačkoj ili Srbiji. Tada bi se status javnobilježničkog pologa kao instrumenta osiguranja plaćanja jasnije regulirao kao ugovorni odnos i stranke bi time dobile na raspolaganje i učinkovitiji instrument osiguranja plaćanja podložan primjeni izričitih pravila.

U ovome trenutku, može se zaključiti, javnobilježnički polog predstavlja učinkovito sredstvo osiguranja plaćanja sudionicima zbog stroge normiranosti uloge javnog bilježnika kao escrow agenta, no postoji daljnja potreba jasnijeg reguliranja pravne naravi javnobilježničkog pologa, kako bi se otklonile određene dvojbe koje nastaju u tumačenju Zakona o javnom bilježništvu. 


\section{SUMMARY}

In the exercise of their profession, the notary public in the Republic of Croatia offers the specific service of the depository of funds, securities and documents by or on behalf of their clients. This service of notary public has become more frequently used in the specific cases where the holding of entrusted funds, securities or documents is necessary to ensure the key obligation, arising from the private transaction between parties, is adequately fulfilled. The specific aim of this paper is to present the legal nature and possible ways of setting up a notary public deposit. From one point of view, the deposit shows a visible feature of an agreement conluded between notary public and client(s) with his specific duties and rights. From the other the role of notary public in deposit function presents a typically general official duty to perform as a trust person within the scope prescribed by Notary Public Act. The medial part of the paper focuses to the possible answers of this key question using the method of legal analysis of legislation, the linguistic approach, teleological interpretation of legal provisions and data compilation using the available legal literature. About the legal nature of this institute depends on which national legal rules should be applied to an eventual dispute. The paper also gives a comparative review from Slovenia, Serbia, Bosnia and Herzegovina, Germany, Russia and Estonia using comparative research method.

Key words: notary public, notary deposit, lease contract, mandate contract, contract of deposit, general official duty of notary public, court deposit 